\title{
Study of Optical Properties of Zinc Oxide Nanostructures Thin Solid Films Using Spin Coating Technique: APrecursor Organic for Electronics Devices Applications
}

\author{
L Castañeda* \\ Sección de Estudios de Posgrado e Investigación de la Escuela Superior de Medicina, Instituto Politécnico Nacional, Plan de San \\ Luis y Díaz Mirón s/n, Casco de SantoTomás, Ciudad de México, A. P. 11340, México
}

*Corresponding author: L Castañeda, Sección de Estudios de Posgrado e Investigación de la Escuela Superior de Medicina, Instituto Politécnico Nacional, México

\section{ARTICLE INFO}

Received: 閟 September 30, 2020

Published: 慧 October 08, 2020

Citation: L Castañeda. Study of Optical Properties of Zinc Oxide Nanostructures Thin Solid Films Using Spin Coating Technique: APrecursor Organic for Electronics Devices Applications. Biomed J Sci \& Tech Res 31(1)-2020. BJSTR. MS.ID.005041.

Keywords: Zinc Oxide Nanostructures; Optical Properties; Plant Extract

PACS: 68.55.-a; 68.55.Jk; 81.10.Dn; 81.15. Rs; 81.15.-z

Abbreviations: ZnO: Zinc Oxide; TCOs: Transparent Conducting Oxides; $\mathrm{NaOH}$ : Sodium Hydroxide; FTIR: Fourier Transform-Infrared Spectroscopy; RPM: Revolution per Minute; eV: Electron Volts

\section{ABSTRACT}

In this research work we synthesized Zinc oxide [ZnO] Nanostructures using plant extracts. Zinc oxide [ZnO] nanostructures were synthesized by solution method and deposited by spin- coating technique. The samples were characterized by UV-Vis spectrophotometer and Fourier-transform infrared spectroscopy (FTIR).The maximum absorption peaks occurred at $235.0 \mathrm{~nm}, 250.0 \mathrm{~nm}, 270.0 \mathrm{~nm}$, and $300.0 \mathrm{~nm}$ respectively but lower when compared with the bulk size that occurred at $350.0 \mathrm{~nm}$ and in the visible spectrum of the wave length band. Band gap energy of zinc oxide nanostructures at 500.0 rpm was $3.8 \mathrm{eV}$. FTIR spectrum was recorded in the range of $4000.0 \mathrm{~cm}^{-1}$ to $500.0 \mathrm{~cm}$ 1. FTIR Observation shows that the bands of ZnO Nanostructures occur at $3903.4 \mathrm{~cm}$ 1, $2802.2 \mathrm{~cm}^{-1}, 2195.9 \mathrm{~cm}^{-1}, 1963.2 \mathrm{~cm}^{-1}, 1834.5 \mathrm{~cm}^{-1}, 1194.7 \mathrm{~cm}^{-1}$, and $682.6 \mathrm{~cm}^{-1}$. The synthesis $\mathrm{ZnO}$ Nanostructures FTIR results how $\mathrm{ZnO}$ functional group was found at low wave number. The result can be used for performance enhancement of solar cell and to develop guide line for fabrication of organic solar cells.

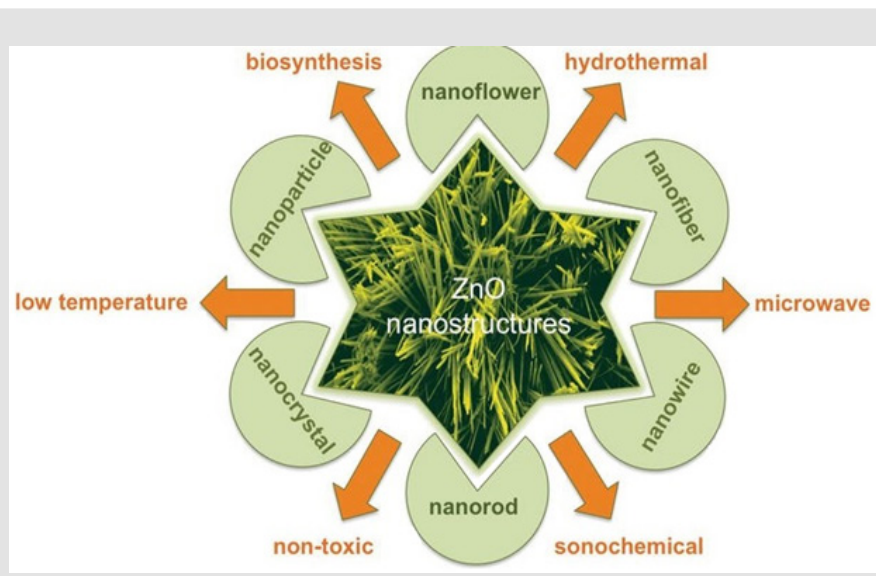

Graphical Abstract 1: Green Organic Synthesis of Zinc oxide Nanostructures.

\section{Introduction}

The branch of technology that studies different materials at a nanometric scale is referred to as nanotechnology and it is also defined as science of production, manipulation and use of materials at subatomic level that find sits application in materials science, 
engineering, and electronics. Recently, transparent conducting oxides (TCOs) have been widely studied. ZnO thin solid films are one of the most prominent transparent conducting oxides for the fabrication of the next generation advanced applications such as window layer in heterojunction solar cells $\mathrm{ZnO}$ is an inorganic material with high electron mobility and easy to prepare as electron acceptor to dissociate excitons formed in conjugated polymer as the active material of solar cells. Zinc oxide is an inorganic material that has found it suspension many applications and can be prepared

as a nanostructure [1-10]. Zinc oxide nanostructures have been widely used as donor material due to its superior optoelectronic properties and it is relatively easy to be synthesized by using the following methods: ultrasound, anodization, co-precipitation, solgel method, chemical vapor deposition and mechano-chemical activation thermal synthesis.

Ramesh, et al., in their research reported that the synthesized $\mathrm{ZnO}$ nanostructures are moderately stable, roughly spherical with maximum particles in size range with in $\mathrm{nm}$ in diameter [10]. Renata Dobrucka and Jolanta Dugaszewka, et al. reported the synthesis of $\mathrm{ZnO}$ nanostructures using Trifoliumpratense flower extract characterized using different methods to study the efficacy of the synthesized $\mathrm{ZnO}$ nanostructures against clinical and standard strain of Staphylococcus aureus and Pseudomonas aeruginosa and standard strain of Escherichia coli [11]. Geetha, et al., in their article Green medicated synthesis and characterization of $\mathrm{ZnO}$ nanostructures using Euphorbia Jatropa latex as reducing agented ported that latex plant played an important role in controlling the size of the particle and its morphology [12]. Fatimah, et al., reported that Mimosa pudica and coffee powder extracts materials have crystallite size of around $27.1 \AA$ and $46.9 \AA$ and that photo-catalytic activity (photo-catalytic activities depend highly on experimental conditions such as the amount of catalyst, light intensity, lighting area, reactor volume, type of reactor, temperature, and pressure.

Intrinsic properties of semiconductor photo-catalysts, such as the particle/crystallite size, phase composition, surface area, surface hydroxyls, lattice defects and type and level of dopants (metals and nonmetals), morphology (powder, nanoparticles, nanotubes, nanorod, and hollow nanospheres), structural features, and photo-physical properties, influence their performance) of $\mathrm{ZnO}$ nanostructures is related to the crystallite size as well as band gap energy values [13]. Matinise, et al., reported that $\mathrm{ZnO}$ nanostructures have a god electrochemical activity and are consider as a potential electrocatalyst [14]. Zinc oxide nanostructures have been widely developed as donor material due to its superior optoelectronic properties and it is relatively easy to be synthesized by using solution methods. Taufiq, et al., used a sol-gel method to synthesis and study ZnO Nanostructures [15]. Fakhari, et al., carried out green synthesis of nanostructures by biological systems they reported peaks absorption around $350.0 \mathrm{~nm}$ due to large excitation binding energy at room temperature $\approx 23.0^{\circ} \mathrm{C}[16]$.
ZnO nanostructures were blended with apoly-3-hexylthiophene as active material for high performance solar cell [17]. Patidar, et al., blended ZnO Nanostructures with Poly(3hexylthiophene-2,5-diyl $)\left[\left(\mathrm{C}_{10} \mathrm{H}_{14} \mathrm{~S}\right)_{\mathrm{n}}\right]$ and an improvement was reported inter chains and intra chains ordering when compared to pure Poly(3-hexylthiophene-2,5-diyl) $\left[\left(\mathrm{C}_{10} \mathrm{H}_{14} \mathrm{~S}\right)_{\mathrm{n}}\right]$ [18]. Power conversion efficiency of solar cells also improved. The objectives of this research are to understand the synthesis of Zinc oxide Nanostructures, to explore the behavior of zinc a nanostructure thin solid films in certain condition and characterizes $\mathrm{ZnO}$ Nanostructures thin solid films. Also, to investigated the optical properties by means of UV-Vis spectroscopy and chemical structure by means of FTIR spectroscopy for performance enhancement for solar cells.

\section{Experimental Details}

\section{Laboratory Instruments and Materials}

The materials used were bashful leaves (Mimosa Pudica). The leaves are bipinnately compound, with one or two pinnae pairs, and 10-26 leaflets per pinna. The petioles are also prickly. Pedunculate (stalked) pale pink or purple flower heads arise from the leaf axils in midsummer with more and more flowers as the plant gets older. The globose to ovoid heads are 8.0-10.0 mm (0.3-0.4 in) in diameter (excluding the stamens). On close examination, it is seen that the floret petals are red in their upper part and the filaments are pink to lavender. Pollens are circular with approximately $8.0 \mu \mathrm{m}$ diameter. Zinc acetate dihydrate, $\left(\left[\mathrm{Zn}\left(\mathrm{CH}_{3} \mathrm{COO}\right)_{2} \cdot 2 \mathrm{H}_{2} \mathrm{O}\right], 99.9 \%\right.$, from SigmaAldrich Química, S.L. Toluca, México), Ethanol ([ $\left.\mathrm{C}_{2} \mathrm{H}_{5} \mathrm{OH}\right], 99.9 \%$, from Sigma-Aldrich Química, S.L. Toluca, México), Sodium hydroxide ([NaOH], 99.9\%, from Sigma-Aldrich Química, S.L. Toluca, México), Beakers glass (A beaker is generally a cylindrical container with a flat bottom, from Sigma-Aldrich Química, S.L. Toluca, México), Petri dish (Petri dishes were traditionally meant to be reusable and made of glass; often of heat-resistant borosilicate glass for proper sterilization at 120.0-160.0 ${ }^{\circ} \mathrm{C}$, from Sigma-Aldrich Química, S.L. Toluca, México), Filter papers (Filter paper is a semi-permeable paper barrier placed perpendicular to a liquid or air flow.

It is used to separate fine substances from liquids or air. It is used in science labs to remove solids from liquids. This can be used to remove sand from water, (from Sigma-Aldrich Química, S.L. Toluca, México). For this purpose, the oven mentioned below was used LCC/LCD Clean Process Lab Oven Despatch's LCC and LCD clean process laboratory ovens have forced airflow recirculation that is $100.0 \%$ HEPA filtered and can maintain ISO Class 5 (Class 100) operation throughout the process cycle. These lab ovens can be stacked up to three high for added capacity in small labs. Nitrogen atmosphere is available, and the maximum temperature is $350.0^{\circ} \mathrm{C}\left(\sim 662.0{ }^{\circ} \mathrm{F}\right)$, Spatula (from Sigma-Aldrich Química, S.L. Toluca, México) is usually used to scrape within the contours of a mixing bowl or to level off the top of a dry mixing cup. It is a tool with two flat edges on a flexible blade, and finally A magnetic stirrer 
or magnetic mixer (IKA C-Mag HS 7, People's Republic of China) is a laboratory device that employs a rotating magnetic field to cause a stir bar (or flea) immersed in a liquid to spin very quickly, thus stirring it. The rotating field may be created either by a rotating magnet or a set of stationary electromagnets, placed beneath the vessel with the liquid. These were some of the instruments used to carry out the research scientist work.

\section{Methodology to Perform the Experiment}

All experimental procedures of preparation of the thin solid films were performed in a glove box (Plas Labs ${ }^{\mathrm{TM}}$ Glove Box 855 - ACB Anaerobic Chamber Manually) control your atmosphere when working with oxygen-sensitive materials in this glove box. Plas Labs ${ }^{\mathrm{TM}}$ Glove Box 855 - ACB Chamber uses a catalyst heater to reduce any trace entering oxygen to water vapor - GLOVE BOX PLAS LABS 855 - ACB/EXP ANAEROBIC CHAMBER, manually controlled atmosphere multi user bright is a sealed container that is designed to allow one to manipulate objects where a separate atmosphere is desired. Built into the sides of the glove box are gloves arranged in such a way that the user can place their hands into the gloves and perform tasks inside the box without breaking containment. Part or the entire box is usually transparent to allow the user to see what is being manipulated.

\section{Substrates Cleaning Procedure}

The cleaning procedure for soda-lime glass substrates is explained in the following lines:

i) A five minute ultrasonic bath in a trichloroethylene ( $\left[\mathrm{C}_{2} \mathrm{HCl}_{3}\right], 99.9 \%$, from Sigma-Aldrich Química, S.L. Toluca, México) was implemented to degrease the substrates, followed by

ii) A five minute bath in a methyl alcohol ([ $\left.\mathrm{CH}_{3} \mathrm{OH}\right], 99.9 \%$, from Sigma-Aldrich Química, S.L. Toluca, México);

iii) A five minute ultrasonic bath in acetone $\left(\left[\mathrm{CH}_{3} \mathrm{COCH}_{3}\right], 99.9\right.$ \%, from Sigma-Aldrich Química, S.L. Toluca, México), and afterward

iv) The substrates were subsequently dried by blowing them with a pure and dry nitrogen ([N2] $99.9 \%$ from PRAXAIR, México) gas flow.

\section{Technique of Preparation of Plant Extract}

Thirty grams (30.0 g) of Ewe patanmon (Yoruba name), bashful leaves (Mimosa Pudica), were collected and washed thoroughly with deionized water $\left[\mathrm{H}_{2} \mathrm{O}\right]$ (Resistivity of water produced at $\sim 23.0$ ${ }^{\circ} \mathrm{C}$, > 5.0 M $\Omega \bullet \mathrm{cm}$, ZLXL62080 Milli-Q, from Merck Milipore, México) to remove dirt and the residual moisture. The leaves were grinded in to powder after dry in gin ambient temperature $\sim 23.0^{\circ} \mathrm{C}, 0.4 \mathrm{~g}$ of the powder sample was added into $40.0 \mathrm{ml}$ of ethanol solvent and stirred for $24.0 \mathrm{~h}$ without heat using magnetic stirrer. The solution was filtered. The extract was stored and kept away from ray of the sun.

\section{Preparation of Aqueous Zinc Acetate Dihydrate Solution}

Zero point two grams were used of $\left[\mathrm{Zn}\left(\mathrm{CH}_{3} \mathrm{COO}\right) 2 \cdot 2 \mathrm{H}_{2} \mathrm{O}\right]$ was dissolved in $20.0 \mathrm{ml}$ of $\left[\mathrm{C}_{2} \mathrm{H}_{5} \mathrm{OH}\right]$ at room temperature $\sim 23.0^{\circ} \mathrm{C}$. The solution was heated at $900.0^{\circ} \mathrm{C}$ for 40.0 min using magnetic stirrer. The solution was left to cool under ambient temperature $23.0^{\circ} \mathrm{C}$.

\section{Synthesis of Zinc Oxide Nanostructures}

In this procedure $0.5 \mathrm{M}$ aqueous solutions of zinc acetate dihydrate is mixed with $10 \mathrm{ml}$ of plant extract which was stirred without heat for $4.0 \mathrm{~h}$ using magnetic stirrer for homogenous mixture. Sodium hydroxide solution was then prepared by mixing it with $0.8 \mathrm{M}$ aqueous use ethanol and stirred without heat for $4.0 \mathrm{~h}$. The two solutions were added together and stirred for 6.0 $\mathrm{h}$ for homogenous mixture and chemical reaction. Zinc Hydroxide $\left[\mathrm{Zn}(\mathrm{OH})_{2}\right]$ is an inorganic chemical compound. It also occurs naturally as three rare minerals: wülfingite (orthorhombic), ashoverite and sweetie (both tetragonal) precipitate that settled at the bottom of thesealed beaker was obtained by removal of excess mother liquor. The precipitate $\left[\mathrm{Zn}(\mathrm{OH})_{2}\right]$ by products was removed by washing with deionized water and acetone. Heating process or baking was carried out at the temperature of $300.0{ }^{\circ} \mathrm{C}$ for $45 \mathrm{~min}$ to evaporate the solvent in a Laboratory Chamber Furnace-ELF (Carbolite Gero USA Verder Scientific, Inc.) and to convert [ $\left.\mathrm{Zn}(\mathrm{OH})_{2}\right]$ into zinc oxidenanostructures.

\section{Analysis of the Samples}

The materials were analyzed using a UV-VIS spectrophotometer (UV-2700, Shimadzu, Japan) is a method of molecular absorption spectroscopy with ultraviolet and visible radiation, simple and inexpensive technique to determine the concentration of an analyte in solution. It can be used for relatively simple analysis, where the type of compound to be analyzed ('analyte') is known, to do a quantitative analysis to determine the concentration of the analytes and Fourier Transform-Infrared Spectroscopy (FTIR) (FTIR Nicolet ${ }^{\mathrm{TM}}$ iS $^{\mathrm{TM}} 50$ U. S. A.) is an analytical technique used to identify organic (and in some cases inorganic) materials. This technique measures the absorption of infrared radiation by the sample material versus wavelength. The infrared absorption bands identify molecular components and structures.

\section{Deposition of Synthesized of Zinc Oxide Nanostructures}

Zinc oxide solution was prepared and deposited onsoda-lime glass substrate at different spin coating speed using spinning coating (model The Process Station Etching, SPS-Europe B.V., Netherlands). Spin coating is one of the most common techniques for applying thin films to substrates (Figure 1). It is used in a wide variety of 
industries and technology sectors. The advantage of spin coating is its ability to quickly and easily produce very uniform thin solid films, ranging from a few nanometers to a few microns in thickness. The use of spin coating in organic electronics and nanotechnology is widespread and has built upon many of the techniques used in other semiconductor industries. It also has some differences due to the relatively thin solid films and high uniformity required for effective device preparation, as well as the need for self-assembly and organization to occur during the casting process. Spin coating speeds of 3000 revolution per minute (rpm), $2000 \mathrm{rpm}, 1500 \mathrm{rpm}$, $1000 \mathrm{rpm}, 750 \mathrm{rpm}$, and $500 \mathrm{rpm}$ were considered respectively for 30 seconds corresponding to thin solid film layer thick nesses of $32 \mathrm{~nm}, 35 \mathrm{~nm}, 87 \mathrm{~nm}, 115 \mathrm{~nm}, 146 \mathrm{~nm}$, and $177 \mathrm{~nm}$ respectively. Depending on the speed of rotation (rpm) of the spin coater, the desirable thickness of the thin solid films was obtained. It is important to note that the thickness of the thin solid film being spin coated depend on both time and speed of rotating stub as specified by equipment manufacturer.Another method of determination of thickness is by using Equation (1) in the absence of surface profile meter.

$$
t=\frac{M_{2}-M_{1}}{A \bullet D}
$$

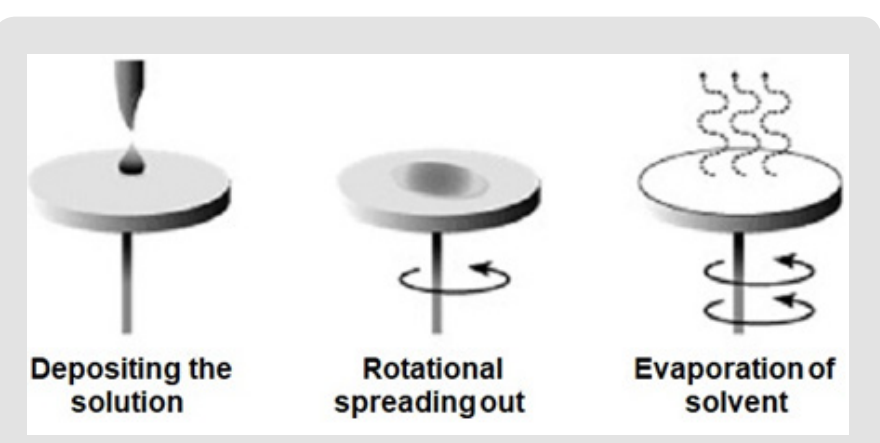

Figure 1: Schematic diagram of the experimental setup used to deposit the samples.

where $t$ is the thickness of the thin solid films (nm), $M_{1}$ is the mass of the sample before deposition, $M_{2}$ is the mass of the sample after deposition, and $\mathrm{A}$ is the Area covered by the thin solid films and D is the Density of the thin solid films.

\section{Zinc Oxide Nanostructures Characterization}

Characterizations of [ZnO] nanostructures were performed to investigate the chemical and optical character of the samples. UV-Vis spectrophotometer and Fourier transform infrared spectroscopy (FTIR) were used for characterization of the samples UV-Vis analysis and absorption properties was obtained using UV-VIS spectrophotometer. The wave length spectrum for which a material absorbs light and produces photo current the 1.0 ps determine that her the material is capable of converting the available light illuminating it in to electric energy. Absorption was chosen as the optimization variable because the choice of layer thickness $(t)$ is critical for optimization of the efficiency. UV-VIS spectrophotometer was used to record the transmittance and reflectance in percentage (\%). The absorbance was calculated using the Equation (2):

$$
A=2-\log (\% T) a . u .
$$

where $\mathrm{A}$ is the absorbance, $\% \mathrm{~T}$ is the percentage transmittance. Band gap energy of ZnO nanostructures was calculated (3) [19-21].

The following relational expression proposed by Tauc, Davis, and Mott is used:

$$
(\alpha h v)^{\frac{1}{n}}=A\left(h v-E_{g}\right)
$$

The value of the exponent $\mathrm{n}$ denotes the nature of the sample transition. For direct allowed transition $n=\frac{1}{2}$, direct forbidden transition $n=\frac{3}{2}$, indirect allowed transition $n=2$, indirect forbidden transition $n=3$. For our case $n=\frac{1}{2}$, therefore equation (3) would be:

$$
(\alpha h v)^{2}=A\left(h v-E_{g}\right) . .
$$

where $(h v)$ is the photon energy the values were determined from the inverse relationship between energy in electron volts [eV] and wavelength of the UV-visible spectrum using the equation (5).

$$
E=\frac{h \bullet c}{q \bullet \lambda}
$$

where $\mathrm{E}$ is the photon energy, $\mathrm{h}$ is planck's constant $(6.626 \times$ $\left.10^{-3} \mathrm{~J} \bullet \mathrm{s}\right), \mathrm{c}$ is the speed of light $\left(3.0 \times 10^{8} \mathrm{~m} / \mathrm{s}\right), \lambda$ is wavelength $\mathrm{q}$ is the electron charge $\left(1.6 \times 10^{-19} \mathrm{C}\right), \alpha$ is the absorption coefficient, $\mathrm{Eg}$ is the optical band gap and $\mathrm{A}$ is the proportional constant.

The energy band gap was obtained from straight line plot of $(\alpha h v)^{2} v s . h v$ by extrapolating of the line to baseline. The absorption coefficient $(\alpha)$ of thin film was calculated using the equation (6) [22].

$$
\alpha=2.3 \bullet\left(\frac{A}{t}\right)
$$

FTIR spectrum of $\mathrm{ZnO}$ nanostructures was obtained from sample deposited at $500 \mathrm{rpm}$ corresponding to $120 \mathrm{~nm}$ thickness.

\section{Results and Discussion}

\section{UV-Vis Spectra Analysis of Zinc Oxide Nanostructures}

Figure 2 shows the transmittance of $\mathrm{ZnO}$ nanostructures deposited at different spin coating speed. The solution at $500 \mathrm{rpm}$ among the deposition at different spin coating speed has the highest absorption value and least transmittance after optical properties characterization in the visible spectrum of wave length band (400 $\mathrm{nm}$ to $900 \mathrm{~nm}$ ) as shown in Figure 3. It can be seen in Figure 4 that 
the absorption spectrum of the $\mathrm{ZnO}$ nanostructures that were made to $500 \mathrm{rpm}$ lies at $230 \mathrm{~nm}$ to $300 \mathrm{~nm}$ in UV spectrum of wavelength band in agreement as reported by Gupta, et al., [23]. The maximum absorption peaks occurred at $230 \mathrm{~nm}, 250 \mathrm{~nm}, 270 \mathrm{~nm}$, and 300 $\mathrm{nm}$ respectively but lower when compared with the bulk size that occurred at $350 \mathrm{~nm}$ and in the visible spectrum of the wavelength band. Figure 5 shows band gap energy graph of zinc oxide nanostructures at $500 \mathrm{rpm}$, the obtained band gap energy was 3.8 $\mathrm{eV}$ which is similar to the research study reported by Taufiq, et al., and Preethi, et al., [15,24]. This shows thickness of plant extract and $\mathrm{ZnO}$ nanostructures composites has effect on photon energy absorption.

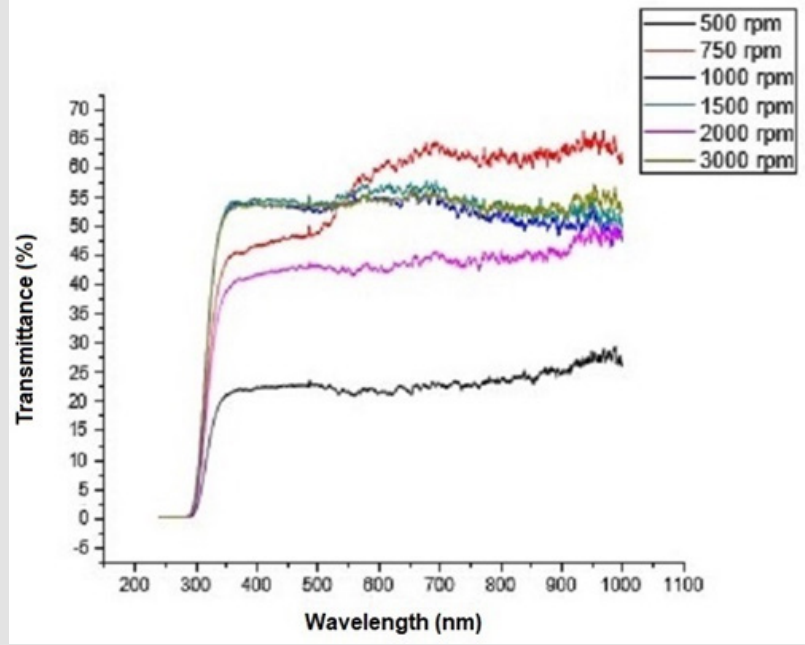

Figure 2: Transmittance versus wavelength graph of Zinc oxide Nanostructures at different spin coating speed.

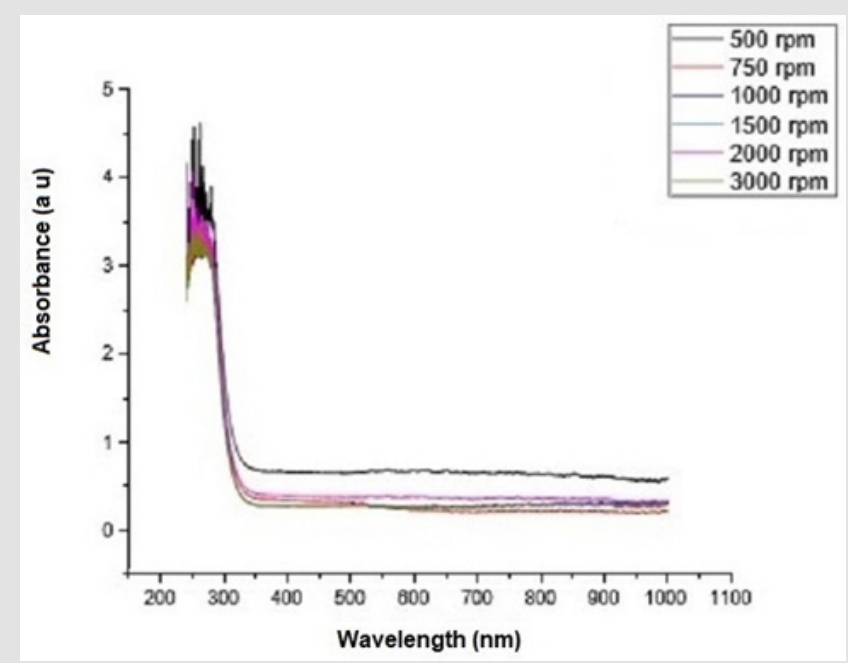

Figure 3: Absorbance versus wavelength graph of Zinc oxide Nanostructures at different spin coating speed.

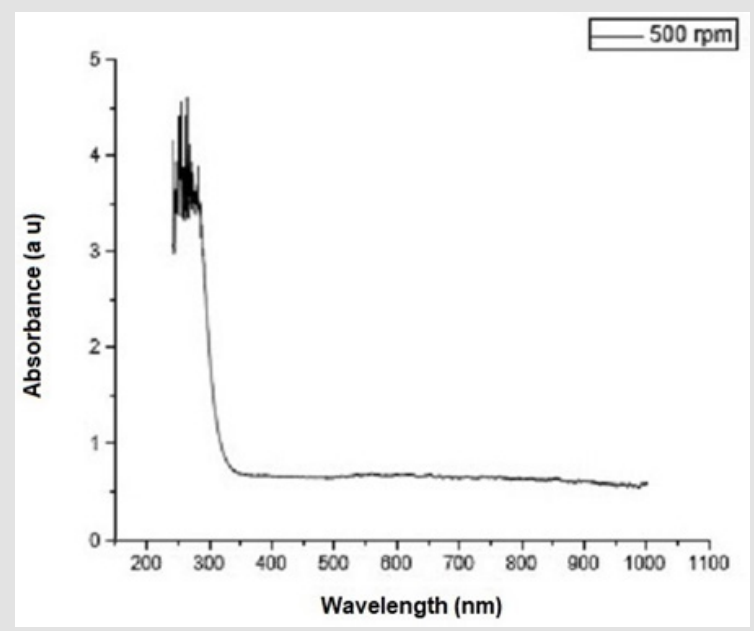

Figure 4: Absorbance versus wavelength graph of Zinc oxide Nanostructures at spin coating speed of $500 \mathrm{rpm}$.

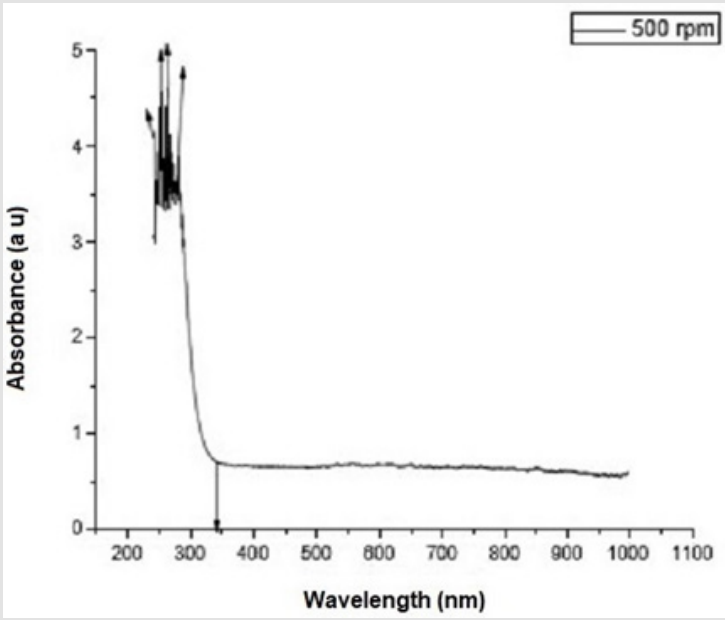

Figure 5: Absorbance versus wavelength graph of Zinc oxide Nanostructures at spin coating speed of $500 \mathrm{rpm}$.

\section{Fourier Transforms Infra-red Spectroscopy Analysis of}

\section{Zinc Oxide Nanostructures}

FTIR spectrum of $\mathrm{ZnO}$ nanostructures was obtained from sample deposited at $500 \mathrm{rpm}$ corresponding to $120 \mathrm{~nm}$ thickness. Figure 6 shows the infrared spectrum of the sample of $\mathrm{ZnO}$ nanostructures that were made to deposited on soda-lime glass substrate at $500 \mathrm{rpm}$. ZnO nanostructures FTIR spectrum was recorded in the range of $4000 \mathrm{~cm}^{-1}$ to $500 \mathrm{~cm}^{-1}$. Observation shows that the bands of ZnO Nanostructures occurs at $3903.4 \mathrm{~cm}^{-1}, 3626.4$ $\mathrm{cm}^{-1}, 2802.2 \mathrm{~cm}^{-1}, 2395.4 \mathrm{~cm}^{-1}, 2195.9 \mathrm{~cm}^{-1}, 1963.2 \mathrm{~cm}^{-1}, 1905.0 \mathrm{~cm}^{-}$ $1,1834.5 \mathrm{~cm}^{-1}, 1643.0 \mathrm{~cm}^{-1}, 1494.9 \mathrm{~cm}^{-1}, 1288.7 \mathrm{~cm}^{-1}, 1194.7 \mathrm{~cm}^{-1}$, $969.8 \mathrm{~cm}^{-1}, 882.6 \mathrm{~cm}^{-1}, 783.4 \mathrm{~cm}^{-1}$ and $682.6 \mathrm{~cm}^{-1}$. The synthesis ZnO nanostructures FTIR result shows $\mathrm{Zn}-\mathrm{O}$ functional group was found at low wave number as shown in Figure 7 and Figure 8 which is similar to results reported $[7,11,15,25-32]$ (Table 1). 


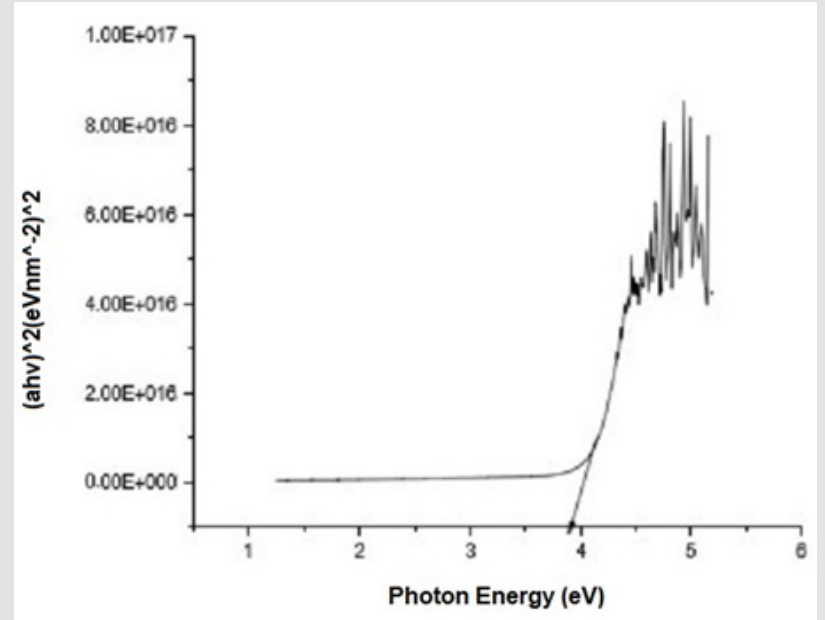

Figure 6: Energy band gap graph of Zinc oxide Nanostructures at spin coating speed of $500 \mathrm{rpm}$.

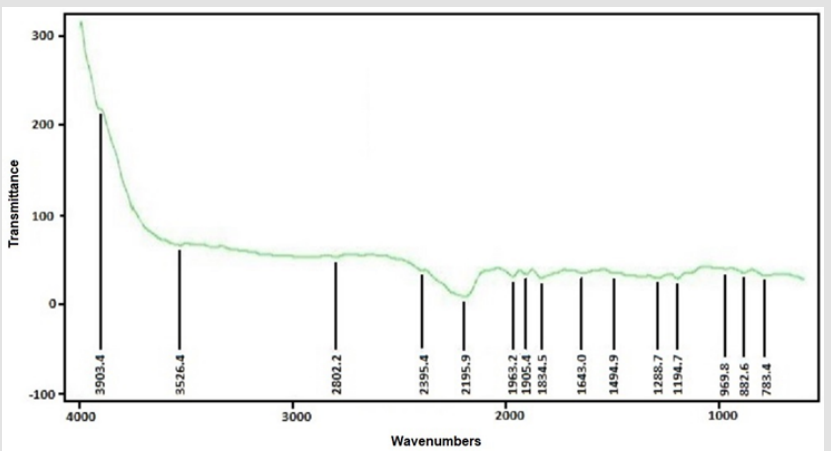

Figure 7: Synthesized Zinc oxide Nanostructures FTIR spectra at $500 \mathrm{rpm}$ using Mimosa Pudica extract.

Table 1: Functional groups of the synthesized the zinc oxide nanostructures using Mimosa Pudica extract.

\begin{tabular}{|c|c|c|}
\hline $\begin{array}{c}\text { Wave Number(cm-1) } \\
\text { data Obtained }\end{array}$ & Functional Group & $\begin{array}{c}\text { Wave Number } \mathbf{( c m}^{-1} \mathbf{~} \\
\text { "References" }\end{array}$ \\
\hline $\begin{array}{c}1494.9,1288.7, \\
1194.7 \\
969.8, \\
882.6,783.3682 .6\end{array}$ & $\begin{array}{c}\text { Zn-OH, Zn-O. } \\
\text { variety of single bond }\end{array}$ & {$[15,27,28,29,30]$} \\
\hline $\begin{array}{c}1963.2, \\
185.5,1905.0, \\
1643.0\end{array}$ & $\begin{array}{c}\text { C=O, C=N, C=C. } \\
\text { absorption caused by } \\
\text { double bonds }\end{array}$ & \\
\hline $\begin{array}{c}2395.4,2195.9 \\
3903.4,3626.4,\end{array}$ & $\begin{array}{c}\text { Absorption caused by } \\
\text { triple bond }\end{array}$ & \\
\hline 2802.2 & $\begin{array}{c}\text { N-H, C-H and O-H } \\
\text { absorption caused by } \\
\text { single bond }\end{array}$ & \\
\hline
\end{tabular}

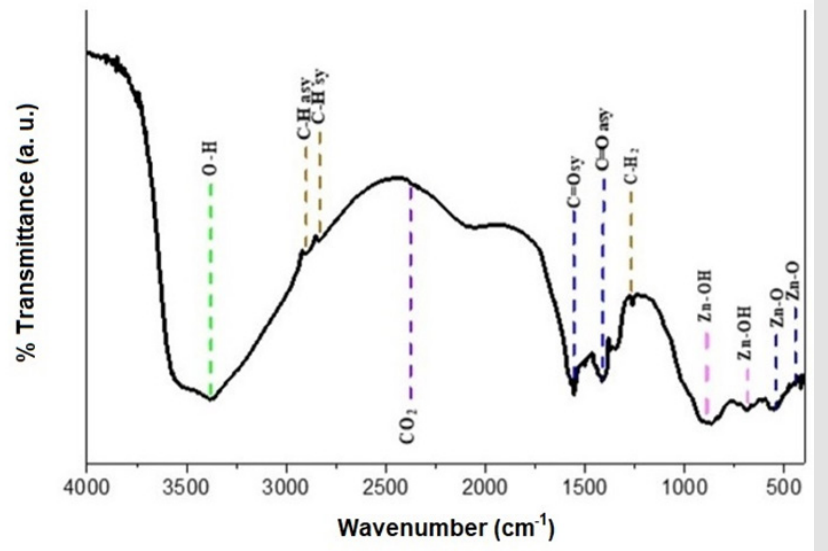

Figure 8: FTIR spectrum of the Zinc oxide Nanostructures.

\section{Research Highlights}

a) Zinc oxide nanostructures using plant extracts.

b) Zinc oxide nanostructures were synthesized by solution method and deposited by spin coating technique.

c) Zinc oxide nanostructures thin solid films were characterized by UV-Vis spectrophotometer and Fourier transform infra-red spectroscopy.

\section{Conclusion}

The research of this scientific work focuses on the $\mathrm{ZnO}$ nanostructures thin solid films based on UV-Vis and FTIR spectrums analysis. UV-Vis spectrum analysis shows $\mathrm{ZnO}$ nanostructures thin solid film has arrange of absorption that occurs from $235 \mathrm{~nm}$ to 300 $\mathrm{nm}$ and $350 \mathrm{~nm}$ upward invisible spectrums. The synthesis $\mathrm{ZnO}$ nanostructures FTIR result shows Zn-O functional group was found at low wave number similar to results reported [7,11,15,33-40]. The main result of this research work can be used to develop guideline for fabrication of solar cells for performance enhancement. It should be noted that future research will be done in order to improve, further refine and understand the full performance of this material.

\section{Acknowledgement}

The authors gratefully acknowledge the financial support from the Escuela Superior de Medicina, Instituto Politécnico Nacional, through Project no. 20200386.

\section{Conflict of Interest}

We declare that we have no conflict of interest.

\section{References}

1. Kumar SS, Venkateswarlu P, Rao VR, Rao GN (2013) Synthesis, Characterization and Optical Properties of Zinc oxide Nanostructures International Nano Letters 3:30.

2. Eric MA (1998) Synthesis and Growth of ZnO Nanostructures. J Phys Chem B 102(29): 5566. 
3. Prasad K, Jha AK (2009) ZnO Nanostructures: Synthesis and Adsorption Study. Natural Science 1(2): 129-135.

4. Sadraei R (2016) A Simple Method for Preparation of Nano-sized ZnO. RRJCHEM 5(2): 45-49.

5. Zhao LH, Zhang R, Zhang J, Sun SQ (2012) Synthesis and characterization of biocompatible $\mathrm{ZnO}$ nanoparticles. CrystEngComm 3(14): 945-950.

6. Vasireddy R, Paul R, Mitra AK (2012) Green Synthesis of Silver Nanostructures and theStudy of Optical Properties. Nanomater Nanotechnol 2(8): 1-6.

7. Alessio Becheri, Maximilian Durr, Pierandrea Lo Nostro, Piero Baglioni (2007) Synthesisand characterization of Zinc oxide nano particles: application to textiles as UV- absorbers. J Nanopart Res 10: 679-689.

8. Vaseem M, Umar A, Hahn Yoon Bong (2010) Growth, Properties, and Applications of Copper Oxide and Nickel Oxide/Hydroxide Nanostructures. Metal Oxide Nanosructures and Their Applications 2: 1-39.

9. Young M (2016) Synthesis of Zinc oxide Nanostructures with different morphology by wet chemistry routes. Doctoral Thesis Submitted in partial fulfilment of the requirements for the award of Doctor of Philosophy of Loughborough University.

10. Ramesh P, Rajendran A, Subramanian A (2014) Synthesis of zinc oxide nano particle from fruit of citrus aurantifolia bychemica and green method Asian Journal of Phyto medicine and Clinical Research 2(4): 189-195.

11. Dobrucka R, Dugaszewka J (2016) Biosynthesis and antibacterial activity of $\mathrm{ZnO}$ nano particles using Trifoliumpratense flower extract Saudi Journal of Biological Science 23(4): 517-523.

12. Geetha MS, Nagabhushang H, Shivananjaiah HN (2016) Green medicated synthesisand characterization of $\mathrm{ZnO}$ nano particles using Euphorbia Jatropalatexas reducing agent. Journal of Science: Advanced Materials and Devices 1: 301-310.

13. Fatimah I, Praditaa RY, Nurfalindaa A (2016) Plant Extract Mediated of $\mathrm{ZnO}$ Nanostructures by Using Ethanol Extract of Mimosa Pudica Leaves and Coffee Powder. Procedia Engineering 148: 43-48.

14. Matinise N, Fuku XG, Kaviyarasu K, Mayedwa N, Maaza M (2017) ZnO nanostructuresvia Moringa Oleifer a green synthesis: physical properties \& mechanism of formation. Applied surface science 406: 339-347.

15. Taufiq A, Ulya HN, Utomo J, Sunaryono, NHidayat, et al. (2018) Structural, Optical, and Antifungal Characters of Zinc oxide Nano particles Prepared by Sol-gel Method. J Phys Conf Ser 1093(1): 012001.

16. Fakhari S, Jamzad M, Fard HK (2019) Green synthesis of zinc oxide nano particles: a comparison, Green Chemistry Letters andReviews, 12(1): 19-24.

17. Ayi Bahtiar, Yayah Yuliah, Lusi Safriani, Nagisa Kawate, Yukio Furukawa (2016) Charge Carriers Motion in P3HT: Capped ZnO Nanostructures Blend Films; Impact of Capping Agents. ICoSE Conference Proceedings.

18. Patidar D, Kaswan A, Saxena NS, Sharma K (2013) Mono dispersed $\mathrm{ZnO}$ Nanostructures and Their Use in Hetero junction Solar Cell. The Scientific World Journal 2013: 260521.

19. Green MA (1982) Solar cells: operating principles, technology and system applications, Prentice-hall, Englewood Cliffs, NJ

20. Tauc J (1972) The optical properties of solids. North-Holland, Amsterdam.

21. Taufiq A, Ulya HN, Utomo J, Sunaryono, NHidayat, et al. (2018) Structural, Optical, and Antifungal Characters of Zinc oxide Nano particles Prepared by Sol-gel Method. J Phys Conf Ser 1093(1): 012001.
22. Kumari KB, Raji P (2011) Synthesis and characterization of nano zinc oxide by gel spin coating. Recent Research in Science and Technology $3(3)$.

23. Gupta A, Srivastava P, Bahadur L, Amalnerkar DP, Chauhan R (2014) Comparison of physical and electrochemical properties of $\mathrm{ZnO}$ prepared via surfactant-assisted precipitation routes. Appl. Nanosci 5: 787-794.

24. Preethi S, Anitha A, Arulmozhi M (2016) A Comparative Analysis of the Properties of Zinc oxide ( $\mathrm{ZnO}$ ) Nanostructures Synthesized by Hydrothermal and Sol-Gel Methods. Indian J Sci Technol 9(40).

25. Xiong G, Pal U, Serrano JG, Ucer KB, Williams RT (2006) Photoluminesence and FTIR study of ZnO nanostructures: the impurity and defect perspective Phys. Status Solidi 3(10): 3577-3581.

26. Hlaing Oo WM, Mc Cluskey MD, Lalonde AD, Norton MG (2005) Infrared spectroscopy of $\mathrm{ZnO}$ nanostructures containing $\mathrm{CO}$ [sub 2] impurities Appl Phys Lett 86073111.

27. Kołodziejczak Radzimska A, Markiewicz E, Jesionowski T (2012) Structural Characterisation of $\mathrm{ZnO}$ Particles Obtained by the Emulsion Precipitation Method J. Nanomater 2012: 656353.

28. Top A, Cetinkaya H (2015) Zinc oxide and zinc hydroxide formation via aqueous precipitation: Effect of the preparation route and lysozyme addition. Mater Chem Phys 167: 77-87.

29. Hasanpour A, Niyaifar M, Asan, Amighian J (2013) Synthesis and characterization of $\mathrm{Fe} 304$ and $\mathrm{ZnO}$ nanocomposites by the sol-gel method. J Magn Mater 33: 441-444.

30. Wahab R, Ansari SG, Kim YS, Seo HK, Kim GS, et al. (2007) Low temperature solution synthesis and characterization of $\mathrm{ZnO}$ nanoflowers Mater. Res. Bull. 42(9): 1640-1648.

31. Zandi S, Kameli P, Salamati H, Ahmadvand H, Hakimi M (2011) Microstructure and optical properties of $\mathrm{ZnO}$ nanostructures prepared by a simple method. Phys B Condens Matter 406(17): 3215-3218.

32. Vafaee M, Ghamsari MS (2007) Preparation and characterization of ZnO nanostructures by a novel sol-gel route. Mater Lett 61: 3265-3268.

33. Barreto G P, Morales G, Quintanilla MLL (2013) Microwave Assisted Synthesis of $\mathrm{ZnO}$ Nano particles: Effect of Precursor Reagents, Temperature, Irradiation Time, and Additives on Nano-ZnO Morphology Development. J Mater 2013: 478681.

34. Babel A, Jenekhea SA (2005) Alkyl chain length dependence of the fieldeffect carrier mobility in region regular poly(3-alkylthiophenes)s. Synth Met 148(2): 169-173.

35. Fatimah I, Praditaa RY, Nurfalindaa A (2016) Plant Extract Mediated of ZnO Nanostructures by Using Ethanol Extract of Mimosa Pudica Leaves and Coffee Powder. Procedia Engineering 148: 43-48.

36. Ji LW, Shih WS, Fang TH, Wu CZ, Peng SM, et al. (2010) Preparation and characteristics of hybrid ZnO-polymer solar cells. J Matter Sci 45: 32663269

37. Patidar D, Kaswan A, Saxena NS, Sharma K (2013) Monodispersed ZnO Nanoparticles and Their Use in Heterojunction Solar Cell. The Scientific World Journal 2013: 260521.

38. Pratt FL (1997) Repolarization of anisotropic muonium in orientationally disordered solids, Philos. Mag Lett, pp. 371-380.

39. Risdiana Fitrilawati, Hidayat R, Nugroho AA, Siregar RE, Tjia MO, et al. (2010) mSR study of electron radicaldynamics in regio-regular polythiophene. Journal of Physics Conf Series 200: 052024-052027.

40. Safriani L, Risdiana R, Bahtiar A, Aprilia A, Siregar RE, et al. (2014) Charge Carrier Dynamics of Active Material Solar Cell P3HT: ZnO Nanostructures Studied by Muon Spin Relaxation ( $\mu$ SR). Advanced Materials Research 896: 477-480. 
ISSN: 2574-1241

DOI: 10.26717/BJSTR.2020.31.005041

L Castañeda. Biomed J Sci \& Tech Res

cC) This work is licensed under Creative

Submission Link: https://biomedres.us/submit-manuscript.php

$\begin{array}{ll}\text { BIOMEDICAL } & \text { Assets of Publishing with us } \\ \text { RESEARCHES } & \text { - Global archiving of articles } \\ \text { - Immediate, unrestricted online access }\end{array}$

